УДК 355.43

Анатолій Анатолійович Лобанов (доктор військових наук, професор)

Руслан Анатолійович Мозговий (кандидат військових наук)

Національний університет оборони Украӥни імені Івана Черняховського, Київ, Украӥна

\title{
ДО ОЦІНЮВАННЯ ЕФЕКТИВНОСТІ УПРАВЛІННЯ ВІЙСЬКАМИ (СИЛАМИ)
}

Воєнна наука завжди розглядала наявність стійкого та безперервного управління військами (силами) як одну з вирішальних умов перемоги, підкреслювала його особливу роль у досягненні успіху в операціях. Виходячи з иъього, впродовж багатовікової історії воєнного мистецтва особливе значення надавалося розвитку органів, засобів та методів керівництва Збройними Силами і управлінню військами. Так само і в сучасних умовах, як в теорії, так і в практичній підготовці військ (сил), питання управління займали і будуть займати одне з найважливіших місць. Військові фахівці провідних крайн вважають, щэо чітко організоване управління військами (силами) може надати істотну перевагу в ході їх застосування.

В статті розглядаються методи оцінювання ефективності управління військами в залежності від випадкових факторів і спосіб математичного опису процесу управління. Запропоновані методи оцінювання надають можливість отримати більи об’єктивну та адекватну оцінку ефективності управління військами (силами) при врахуванні різних часткових показників.

Ключові слова: модель, метод, система управління, ефективність.

\section{Вступ}

Постановка проблеми. Дослідженнями в області воєнного мистецтва встановлено, що при рівності бойових потенціалів угруповань військ перевага однієї із сторін може бути досягнута за рахунок більш досконалого управління, яке може підвищити бойовий іiі потенціал на 25 \%, і навіть більше [1]. У збройних силах провідних держав світу робиться усе можливе для досягнення необхідного рівня якості управління [2]. Прикладом цьому є впровадження інформаційних технологій в управління багатонаціональними силами в операції "Свобода Іраку”, що дозволило (за даними іноземних засобів інформації) підвищити їх ефективність більше ніж у 2 рази. Отже, питання оцінювання ефективності управління військами завжди були одними 3 найважливіших i актуальність їх 3 часом тільки підвищується.

Аналіз останніх досліджень і публікацій. Під час оцінювання ефективності управління військами широко застосовується моделювання операції (бойових дій), яке полягає у встановленні якісних та кількісних зв язків між умовами ведення бойових дій, параметрами рішення командувача (командира) та плану операції (бою) i властивостями управління військами [1].
При побудові моделі управління військами (силами) процеси, які складають сутність операції (бойових дій), певним чином спрощуються i схематизуються. Із множини факторів, що впливають на них, обирається порівняно невелика кількість найважливіших i отримана схема описується за допомогою того чи іншого методичного апарату залежно від методів оцінювання ефективності.

Загальних способів побудови моделей не існує. У кожному конкретному випадку модель будується із цільової спрямованості операції (бойових дій) і завдання дослідження.

Таким чином завдання удосконалення існуючого науково-методичного апарату оцінювання ефективності управління військами залишається актуальним завданням, необхідність вирішення якого диктується нагальними потребами теорії і практики управління військами.

Метою статті $\epsilon$ аналіз методів оцінювання ефективності функціонування системи управління військами.

\section{Виклад основного матеріалу} дослідження

Оцінювання ефективності управління військами може здійснюватися різними методами.

Найбільшого застосування набули методи ретроспективного аналізу, фізичного 
моделювання, математичного моделювання i експертних оцінок. Розглянемо докладніше їх сутність [4].

Метод ретроспективного аналізу базується на вивченні досвіду управління військами у ході операцій (бойових дій) минулих війн і військових конфліктів. Критерієм ефективності управління військами тут виступає порівняння фактичного результату операцій (бойових дій), з тим, що був визначений (потрібний). Недолік даного методу полягає у наявності лише одного результату операції (бойових дій), що знижує об’єктивність результатів аналізу.

Метод фізичного моделювання операчій (бойових дій) пов'язаний з проведенням тактичних, командно-штабних навчань, воєнних ігор у ході яких по фактичних результатах дій сторін можна зробити висновки про доцільність тієї чи іншої організації управління військами. Цей метод потребує значних ресурсних затрат, тому що для отримання достатньо стійких результатів необхідно проводити велику кількість навчань.

Уникнути недоліків попередніх методів дозволяє метод математичного моделювання операцій (бойових дій). Він заснований на побудові математичних залежностей, які дозволяють імітувати хід і результат операції (бойових дій) сторін, тобто математичних моделей.

Під математичною моделлю операції (бойових дій) розуміють систему математичних залежностей i логічних правил, яка дозволяє 3 необхідною повнотою i у відповідному взаємозв'язку імітувати найсуттєвіші реальні сторони операції (бойових дій) і 3 заданою точністю визначити значення показників ефективності.

До найважливіших ознак класифікації математичних моделей відносяться ступень урахування в моделі випадкових факторів і спосіб математичного опису процесу.

За наявністю або відсутністю урахування випадкових факторів моделі можна поділити на детерміновані і стохастичні. У детермінованих моделях відображаються процеси, в яких відсутні випадкові події. Стохастичні моделі передбачають обчислення показників при імовірнісному характері процесів, які імітуються.

За способом математичного опису процесів, які проходять у складній системі, моделі можна поділити на аналітичні та імітаційні.

Для аналітичного моделювання характерно те, що зв'язок між умовами операцій (бойових дій) i ïх результатом встановлюється за допомогою алгебраїчних, диференціальних, інтегральних рівнянь, логічних умов та інших функціональних співвідношень. Їх перевагою $\epsilon$ те, що в цих моделях знаходяться явні залежності між показниками і параметрами. Однак на практиці залежності, що необхідні, можна отримати тільки для дуже простих умов. Часто, бажаючи мати рішення в явному вигляді, йдуть на значне спрощення аналітичної моделі, що погіршує точність результату.

Нижче наведені декілька прикладів підходів до аналітичного моделювання визначення ефективності функціонування системи управління військами.

Підxід 1. Оскільки управління військами передбачає за планом вирішення певного комплекту оперативних завдань в операції (бойових діях) то його ефективність, безумовно, залежатиме від результатів вирішення цих оперативних завдань. Отже, ефективність функціонування системи управління 3 аспекту способу ведення операції (бойових дій), який визначає певну послідовність вирішення оперативних завдань, можна розглядати як ступінь реалізації усього об'єму оперативних завдань, що визначені у плані (замислі) операції [5].

$$
\mathrm{E}_{\mathrm{cy}}=\frac{\sum_{\mathrm{i}=1}^{\mathrm{n}} \mathrm{Z}_{\mathrm{SRi}}}{\sum_{\mathrm{i}=1}^{\mathrm{n}} \mathrm{Z}_{\mathrm{SBi}}}
$$

де: $\mathrm{E}_{\text {су }}$ - ефективність системи управління військами;

$\mathrm{Z}_{\mathrm{SRi}}$ - оперативне завдання, яке реалізовано в ході операції;

$\mathrm{i} \in\{1, \ldots, \mathrm{n}\}$ - множина оперативних завдань;

$\mathrm{Z}_{\mathrm{SBi}}$ - оперативні завдання, які заплановані до виконання в ході операції.

Підxід 2. Під ефективністю функціонування системи управління можна розуміти ступінь реалізації потенційних оперативних (бойових) спроможностей угруповання військ, військових частин і підрозділів, на які здійснює прямий вплив система управління. Оперативні, бойові та спеціальні спроможності угруповання військ здатність угруповань військ (сил) виконувати певні завдання (забезпечувати реалізацію визначених військових цілей) за певних умов обстановки, ресурсного забезпечення та відповідно до встановлених стандартів. Оперативні, бойові спроможності включають ударні, вогневі та маневрені можливості, рознесені за масштабом (відповідно для оперативних, оперативно-тактичних i тактичних угруповань військ, військових частин і підрозділів). За такого підходу ефективність функціонування системи управління військами можна розглядати як ступінь 
реалізації оперативних (бойових) спроможностей угруповання в операції (бойових діях) та визначаться виразом (2):

$$
\mathrm{E}_{\mathrm{cy}}=\frac{\sum_{\mathrm{i}=1}^{\mathrm{n}} \mathrm{B}_{\mathrm{Pi}}}{\sum_{\mathrm{i}=1}^{\mathrm{n}} \mathrm{B}_{\Pi \mathrm{i}}},
$$

де: $\mathrm{E}_{\text {су }}$ - ефективність системи управління військами;

$\mathrm{B}_{\mathrm{Pi}}$ - оперативні (бойові) спроможності, які були реалізовані в ході операції (бойових діях), $\mathrm{i} \in\{1, \ldots, \mathrm{n}\}$;

$\mathrm{B}_{\text {Пі }}-$ потенційні оперативні (бойові) спроможності.

Пiдxiд 3. На систему управління військами покладається виконання низки завдань, основними з яких є:

підтримання готовності штабів до управління військами;

підтримання високого рівня бойової готовності військ;

безперервне добування, збір, вивчення, відображення i аналіз даних обстановки i прогнозування ii розвитку; вироблення (уточнення) замислу операції (бойових дій);

формулювання (уточнення) рішення;

доведення завдань до підлеглих частин

(підрозділів);

планування (уточнення плану) операції

(бойових дій);

організація (відновлення) управління

військами;

організація (відновлення) і підтримка взаємодії; організація забезпечення військ;

організація і здійснення контролю та надання допомоги підлеглим штабам і військам.

Відповідно, в такому аспекті ефективність функціонування системи управління військами угруповання доцільно розглядати як ступінь своєчасного виконання покладених завдань управління в ході операції (бойових дій), вираз (3):

$$
\mathrm{E}_{\mathrm{cy}}=\frac{\sum_{\mathrm{i}=1}^{\mathrm{n}} \mathrm{Z}_{\mathrm{Pi}}}{\sum_{\mathrm{i}=1}^{\mathrm{n}} \mathrm{Z}_{\mathrm{Bi}}}
$$

де: $\mathrm{E}_{\text {су }}$ - ефективність функціонування системи управління військами;

$\mathrm{Z}_{\mathrm{Pi}}$ - завдання (з управління) системи управління військами, яке було реалізоване в ході ведення операції (бойових дій), де $\mathrm{i} \in\{1, \ldots, \mathrm{n}\}$ множина завдань (з управління) покладених на систему управління;

$\mathrm{Z}_{\mathrm{Bi}}$ - завдання (з управління) системи управління, яке було сплановано до виконання, де $\mathrm{i}=\overline{1, \mathrm{n}}$.

Підхід 4. Відповідно теорії управління військами до функціонування системи управління військами висувається ряд вимог:

високий рівень готовності до функціонування;

забезпечення можливості як централізованого, так і децентралізованого управління військами (силами);

оперативність;

стійкість;

безперервність;

скритність;

якість.

Отже, щоб функціонування системи управління військами було ефективним повинні виконуватися усі вимоги, причому 3 розвитком теорії військового мистецтва ці вимоги можуть зазнавати змін. Чим менше виконуються (або взагалі будьяка не виконується) зазначені вимоги, тим менше буде ефективність функціонування системи управління військами. Отже, ступінь відповідності цим вимогам також можна розглядати як ефективність функціонування системи управління.

Таким чином, система управління буде ефективна, коли всі пii показники (які характеризують відповідність вимогам, що висуваються до неї) будуть відповідати потрібним (мінімально допустимим) значенням, або бути близькими до них.

В такому випадку ефективність функціонування системи управління буде ступінь реалізації вимог, що висуваються до неї та визначатися виразом (4):

$$
\mathrm{E}_{\mathrm{cy}}=\frac{\sum_{\mathrm{i}=1}^{\mathrm{n}} \mathrm{R}_{\mathrm{Pi}}}{\sum_{\mathrm{i}=1}^{\mathrm{n}} \mathrm{R}_{\mathrm{i}}}
$$

де: $\mathrm{E}_{\text {су }}$ - ефективність системи управління військами;

$\mathrm{R}_{\mathrm{Pi}}$ - вимога до функціонування системи управління, яка була виконана в ході ведення операції (бойових дій), $i \in\{1, \ldots, n\}$ - множина вимог до СУ;

$\mathrm{R}_{\mathrm{i}}$ - вимоги, які висуваються до системи управління.

Однак цей підхід має низку суттєвих недоліків.

По-перше, в різних умовах обстановки і на різних етапах підготовки i ведення операції (бойових дій) значення різних вимог, які висуваються до управління військами, не $\epsilon$ 
однаковими. Крім цього деякі вимоги $\epsilon$ взаємозалежними, наприклад, “скритність” і “стійкість”, “стійкість” і “безперервність”, “оперативність”. Оскільки ці особливості дуже складно формалізувати і урахувати, то під час згортання часткових показників в інтегральний можуть виникнути значні помилки.

По-друге, отриманий інтегральний показник ( $\kappa_{\mathrm{y}}$ ) вже достатньо складно інтерпретувати, тобто чітко визначити його фізичний смисл.

I, нарешті, по-третє, при такому підході до оцінювання ефективності управління військами критерій, що застосовується, не має прямого зв'язку з кінцевою метою операції (бойових дій). I це головний недолік, бо створення системи управління військами, навіть самої досконалої - не самоціль, а лише засіб, призначений для забезпечення ефективного виконання завдань операції (бойових дій).

Підхід 5. Аналіз циклу управління, який створюється системою управління, показує, що в цьому процесі чітко проявляються чотири головних етапи:

збір інформації (даних) та оцінювання обстановки;

вироблення замислу і формулювання рішення;

доведення завдань до підлеглих військових частин і підрозділів;

контроль виконання поставлених завдань.

Якщо розглядати, що кожен етап-цикл реалізує своєрідна підсистема, то рішення завдання по визначенню ефективності функціонування системи управління можна звести, у кінцевому результаті, до оцінювання ефективності реалізації кожного зі згаданих етапів циклу управління, тобто ефективності функціонування підсистем збору інформації (даних) та оцінювання обстановки; вироблення замислу і формулювання рішення; доведення завдань до підлеглих військових частин і підрозділів; контролю виконання поставлених завдань.

У такому випадку ефективність функціонування системи управління буде визначатися виразом (5).

$$
\left\{\begin{array}{l}
\mathrm{E}_{\text {су }}=\mathrm{f}\left(\mathrm{E}_{\mathrm{CИ}} ; \mathrm{E}_{\mathrm{BP}} ; \mathrm{E}_{\text {Дз }} ; \mathrm{E}_{\mathrm{K}}\right) \\
\mathrm{E}_{\text {су }} \geq \mathrm{E}_{\text {су }}^{\text {потр }}
\end{array}\right.
$$

де: $\mathrm{E}_{\text {су }}$ - ефективність функціонування системи управління військами;

$\mathrm{E}_{\mathrm{CИ}} \quad-$ ефективність функціонування підсистеми збору інформації;

$\mathrm{E}_{\mathrm{BP}} \quad-$ ефективність функціонування підсистеми вироблення рішення;
$\mathrm{E}_{\text {дз }}-$ ефективність функціонування підсистеми доведення завдань до підлеглих;

$\mathrm{E}_{\mathrm{K}} \quad-$ ефективність функціонування підсистеми контролю;

$\mathrm{E}_{\text {су }}^{\text {потр }}-$ потрібний рівень ефективності функціонування системи управління військами.

У подальшому як критерій ефективності використовується або критерій максимального результату (коли вирішується завдання максимізації рівня ефективності управління) $\kappa_{\mathrm{y}}=\mathrm{K}_{\mathrm{ymax}}$, або критерій придатності (коли вирішується завдання досягнення потрібного рівня ефективності управління) $\mathrm{K}_{\mathrm{y}} \geq \mathrm{K}_{\text {потр }}$, де $\mathrm{K}_{\text {потр }}-$ потрібний рівень ефективності управління військами.

Підхід 6. Виходячи з визначення, що система управління військами - це сукупність функціонально і ієрархічно пов'язаних між собою підсистем органів управління, пунктів управління та системи зв'язку і АСУ, стає можливим запропонувати ще один підхід до оцінювання ii ефективності.

Оцінювання ефективності системи управління в цілому можна визначити як ефективність функціонування ऑii складових підсистем. При цьому слід мати на увазі, що загальна ефективність системи управління не $\epsilon$ простою сумою ефективності ії елементів, вона буде мати вигляд (6):

$$
\left\{\begin{array}{l}
\mathrm{E}_{\mathrm{Cy}}=\mathrm{f}\left(\mathrm{E}_{\mathrm{CO}} ; \mathrm{E}_{\mathrm{C \Pi у}} ; \mathrm{E}_{\mathrm{C3}}\right) \\
\mathrm{E}_{\mathrm{Cy}} \geq \mathrm{E}_{\mathrm{Cy}}^{\text {потр }}
\end{array}\right.
$$

де $\mathrm{E}_{\mathrm{Cy}}$ - ефективність функціонування системи управління військами;

$\mathrm{E}_{\mathrm{COY}}-$ ефективність функціонування підсистеми органів управління;

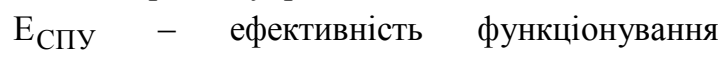
підсистеми пунктів управління;

$\mathrm{E}_{\mathrm{C} 3}-$ ефективність функціонування підсистеми зв'язку та АСУ;

$\mathrm{E}_{\mathrm{CУ}}^{\text {потр }}$ - потрібний рівень ефективності функціонування системи управління військами.

Усі наведені вище підходи досить прості, складність полягає у визначенні (знаходженні) значень часткових показників (складових) ефективності функціонування системи управління військами. Твердження “чим краще функціонує система управління військами, тим вище ефективність ведення операції (бойових дій)" в принципі може бути правильним. Але, в ньому міститься велика невизначеність, так як успіх операції (бойових дій) військ буде залежати 
великою мірою від протидії (впливу) противника, стану, оперативних (бойових) можливостей підлеглих військ, а також їх бойової готовності.

Саме тому, завдання щодо визначення кількісного внеску системи управління військами в досягнення кінцевої мети операції є складною і важливою одночасно. Ефективність функціонування будь-якої системи може (повинна) мати кількісну міру і виражатися числом. При цьому, для прийняття рішень командувачу дуже важливо мати методику оцінювання ефективності системи управління, яка має чітко характеризувати стан системи управління.

У тих випадках, коли побудову аналітичної моделі операції (бойових дій) важко здійснити, застосовується інший, імітаційний метод моделювання, відомий під назвою методу статистичних випробувань чи методу МонтеКарло. Його ідея полягає у наступному. Замість опису випадкових подій, які у сукупності характеризують операцію (бойові діï) математичними залежностями проводиться розіграш-моделювання випадкових подій за допомогою деякої процедури, яка дає випадковий результат (наприклад, датчика випадкових чисел). При цьому параметри, що цікавлять, задаються певним діапазоном значень. У результаті розіграшу отримується одна реалізація результату операції (бойових дій). Здійснивши такий розіграш

\section{Jimepamypa}

1. Алтухов П.К. Основы теории управления войсками. Москва: Воениздат, 1984. 221 с. 2. A.Lobanov, A.Loishyn; I. Tkach, I. Liashenko, A. Zinchenko. Research of main international approaches for risk management process's standardization in the context of internal control standardization in the Armed Forces of Ukraine and providing national security. Revista ESPACIOS. Vol. 40 (Number 20) Year 2019. Page 14. 3. Скрите управління військами: навч. посіб. / О.Я Зубов; В.С.Безбах та ін. Київ: НУОУ, 2017. 72 с. 4. Лобанов А.А., Зубов О.Я. Науково-методичні засади оцінювання та аналізу управлінських рішень прийнятих під час заходів оперативної підготовки. Труди велику кількість разів, отримуємо статистичний матеріал - множину результатів реалізації операції (бойових дій), який для визначення показників ефективності обробляється звичайними методами математичної статистики.

\section{Висновки й перспективи подальших} досліджень

3 викладеного зрозуміло, що цілям дослідження процесів, які проходять під час підготовки і у ході ведення операції (бойових дій), найбільш підходять імітаційні моделі.

У випадках, коли відсутня ретроспектива і для оцінювання ефективності управління військами немає можливості застосувати методи моделювання, використовується метод експертних оцінок. Сутність його полягає у тому, що необхідне рішення приймається на основі оцінки досвідчених в цій області людей - експертів. При цьому оцінки експертів певним чином формалізуються i обробляються спеціальними методами.

Отже, завдання удосконалення існуючого науково-методичного апарату оцінювання ефективності управління військами залишається актуальним завданням, необхідність вирішення якого диктується нагальними потребами теорії i практики управління військами.

університету: збірник наукових праць Національного університету оборони України імені Івана Черняховського. 2018. № 5 (150). С. 97-106. 5. Лобанов А.А., Ролін І. Ф., Марущенко В. В. Управління як функція ведення воєнних дій силами оборони України. Наука і оборона. 2019. № 1. С. 9-15. 6. Оцінювання та порівняння рішень сторін у двосторонніх командноштабних навчаннях (воєнних іграх): навч. посіб. / О.Я Зубов; В.С. Безбах, Р.Ф. Факадей, А.А. Лобанов. Київ: НУОУ, , 2018. 83 с. 7. Гайдес М.А. Общая теория систем. Системы и системный анализ. Винница: ГлобусПресc. 2004. 430 c.

\title{
К ОЦЕНКЕ ЭФФЕКТИВНОСТИ УПРАВЛЕНИЯ ВОЙСКАМИ (СИЛАМИ)
}

\author{
Анатолий Анатольевич Лобанов (доктор военных наук, професор) \\ Руслан Анатольевич Мозговой (кандидат военных наук)
}

\section{Национальный университет обороны Украины имени Ивана Черняховского, Киев, Украина}

Военная наука всегда рассматривала наличие устойчивого и непрерывного управления войсками (силами) как одну из решающих условий победы, подчеркивала его особую роль в достижении успеха 8 операциях. Исходя из этого, на протяжении многовековой истории военного искусства особое значение придавалось развитию органов, средств и методов руководства Вооруженными Силами и управлению войсками. Так же и в современных условиях, как в теории, так и в практической подготовке войск (сил), вопросы управления занимали и будут занимать одно из важнейших мест. Военные специалисть 
ведущих стран считают, что четко организованное управление войсками (силами) может оказать существенную преимущество в ходе их применения.

В статье рассматриваются методы оченки эффективности управления войсками в зависимости от случайных факторов и способ математического описания прочесса управления. Предложенные методы оценки дают возможность получить более объективную и адекватную оценку эффективности управления войсками (силами) при учете различных частных показателей.

Ключевые слова: модель, метод, система управления, эффективность.

\title{
TO EVALUATE THE EFFECTIVENESS OF THE ARMY (FORCE) MANAGEMEN
}

\author{
Anatolii Lobanov (Doctor of Military Sciences, Professor) \\ Ruslan Mozghovyi (Candidate of Military Sciences)
}

\section{National Defence University of Ukraine named after Ivan Cherniakhovsky, Kyiv, Ukraine}

Military science has always considered the existence of a steady and continuous command of troops (forces) as one of the decisive conditions for victory, emphasizing its special role in achieving success in operations. On this basis, throughout the centuries-old history of martial arts, special emphasis has been placed on the development of the organs, means, and methods of commanding and controlling the Armed Forces. Similarly, in modern conditions, both in theory and in the practical training of troops (forces), management issues have occupied and will occupy one of the most important places. Leading military experts believe that a well-organized command of forces (forces) can provide a significant advantage in the course of their deployment.

The article discusses methods of assessing the effectiveness of military control depending on random factors and a method for mathematically describing the control process. The proposed assessment methods make it possible to obtain a more objective and adequate assessment of the effectiveness of military (force) management, taking into account various partial indicators.

Key words: model, method, control system, efficiency.

\section{References}

1. Altukhov P.K. Osnovы teoryy upravlenyia voiskamy. Moskva: Voenyzdat, 1984. 221 s. 2. A.Lobanov, A.Loishyn; I. Tkach, I. Liashenko, A. Zinchenko. Research of main international approaches for risk management process's standardization in the context of internal control standardization in the Armed Forces of Ukraine and providing national security. Revista ESPACIOS. Vol. 40 (Number 20) Year 2019. Page 14. 3. Skryte upravlinnja vijsjkamy: navch. posib. / O.Ja Zubov; V.S.Bezbakh ta in. Kyjiv: NUOU, 2017. 72 s. 4. Lobanov A.A., Zubov O.Ja. Naukovo-metodychni zasady ocinjuvannja ta analizu upravlinsjkykh rishenj pryjnjatykh pid chas zakhodiv operatyvnoji pidghotovky.
Trudy universytetu: zbirnyk naukovykh pracj Nacionaljnogho universytetu oborony Ukrajiny imeni Ivana Chernjakhovsjkogho. 2018. \# 5 (150). S. 97-106. 5. Lobanov A.A., Rolin I. F., Marushhenko V. V. Upravlinnja jak funkcija vedennja vojennykh dij sylamy oborony Ukrajiny. Nauka i oborona. 2019. № 1. S. 9-15. 6. Ocinjuvannja ta porivnjannja rishenj storin $u$ dvostoronnikh komandno-shtabnykh navchannjakh (vojennykh ighrakh): navch. posib. / O.Ja Zubov; V.S. Bezbakh, R.F. Fakadej, A.A. Lobanov. Kyjiv: NUOU, , 2018. 83 s. 7. Haides M.A. Obshchaia teoryia system. Systemы у systemnы analyz. Vynnytsa: Hlobus-Press. 2004. $430 \mathrm{~s}$. 